an analysis of the type of employment of American scientists in 1951 and of their average annual salary.

Of 1,320 who obtained the degree of Ph.D. in mathematics, 88.0 per cent went into educational institutions, $6 \cdot 1$ per cent into govermment service and 5.9 per cent went into industry. For other subjects the statistics relate to Ph.D.'s and B.Sc.'s and are interesting in that the figures for the latter show a marked preponderance for industry as against educational institutes. The numbers, with the percentages going to educational institutes, government service and industry shown in brackets, are as follows : chemistry Ph.D.'s 11,568 $(32 \cdot 5,7 \cdot 4,60 \cdot 1)$ and B.Sc.'s $25,086(4 \cdot 8,8 \cdot 6,86 \cdot 6)$; chemicai engineering Ph.D.'s $854(30 \cdot 1,2 \cdot 7,67 \cdot 2)$ and B.Se.'s $8,251(0 \cdot 7,4 \cdot 1,95 \cdot 2)$; and physics Ph.D.'s 2,784 $(58 \cdot 4,10 \cdot 7,30 \cdot 9)$ and B.Sc.'s $1,365(21 \cdot 4,23 \cdot 9$, 54.7). Average annual salaries were highest for graduates in chemical engineering; they were about equal for graduates in chemistry and in physics, with mathematics and psychology appreciably lower and approximately equal. Except for physics, where salaries in Government service and in industry, at least at the doctorate level, tended to be equal, average salaries were highest in industry and lowest in educational institutions.

During the year the Foundation made 173 grants totalling 1,698,150 dollars for the support of basic research in the biological, medical, mathematical, physical and engineering sciences at 85 institutions. Seventy-two of these grants, totalling 798,800 dollars, were for biological and medical research, and $\boldsymbol{a}_{\mathrm{s}}$ hundred, totalling 866,550 dollars, were for research in the physical, mathematical and engineering sciences, chemistry ( 28 , totalling 206,500 dollars) and physics (22, totalling 282,400 dollars) receiving the greater part. The conference on physics research in colleges, already noted, recommended that, in evaluating proposals, besides the intrinsic significance of the proposed research, emphasis should be placed on the probable value of the project to the educational work of the institution. It was also suggested that projects which involve the participation of students should be encouraged and that due weight should be given to the promise and ability of the prineipal investigator.

In further illustration of the Foundation's understanding of basic research, the report gives a number of examples of investigations currently supported. of the type involving observation and description are B. Maguire's exploration of the botanical resources of the Guayana Highland of British Guiana, S. D. Durrant's study of mammals on the Aquarius Plateau in the Henry and Abajo Mountains of Southern Utah, and T. H. Bullock's study of the pit organ of pit vipers. Among investigations concerned with the development of tools and instruments are M. Jakob's study of bubble formation, heat flow and other aspects of boiling, explorations of the upper atmosphere at the Ionosphere Research Laboratory, Pennsylvania State College, and the construction and operation of a radio telescope at Harvard College Observatory, under the direction of B. J. Bok. In the field of measurement, grants have been given for investigations of an unchanged component of cosmic radiation called $N$-rays, believed to be mostly highenergy neutrons. Several research projects which involve the design of suitable models for dealing with difficult problems were also being supported : these include a laboratory model of the photosynthesis of sugar and cellulose and of the biochemical reactions responsible for the luminescence of fireflies. Grants for the development of concepts include one for the development of a new conceptual basis for probability, and those for testing concepts include a grant to study regeneration of tissue (particularly to attempt to find a growth-inhibiting substance in the adult tissue) and one to test the assumption that cosmic radiation has been constant during the past thirty thousand years by measuring the radioactive carbon content in sediments at the bottom of the ocean.

Of the 557 fellowships awarded for the academic year 1953-54, 42 were made to post-doctoral candidates and 175 to those who had received awards in $1952-53 ; 180$ went to first-year graduate students, 166 to those in their second year, and 169 to those in their final pre-doctorate year. Chemistry claimed 129 fellowships, physies and astronomy 115, engineering 63 , mathematics 56 , zoology 38 , biochemistry 35 , geosciences 26 , botany 19 , microbiology 18 , geophysics 14, medical sciences 14, genetics 11, psychology and anthropology 10, and agriculture 9. In view of the increasing number of applications $(3,300$ as against 3,000 in $1952-53)$ the Foundation published an 'honourable mention list' of 1,274 applicants.

During the five years 1948-52, bachelor's degrees in science, engineering and agriculture totalled about 95,000 a year, and doctor's degrees in the same fields 4,660 ; for $1953-57$ the comparable estimates are 66,800 and 5,420 , respectively ; but it is expected that the downward trend will be reflected in doctorate awards from 1956 onwards. Graduate enrolment at the first year in all fields of science fell from about 12,000 during $1951-52$ to about 8,000 during 195253. So far, the Foundation has not asked Congress for funds to support a scholarship programme but is attempting to increase the supply of young scientific workers by improving the teaching of science. The Foundation has also established an Advisory Panel on Scientific Information, and preliminary inquiry suggests that the most important information in unclassified research reports reaches scientific workers through established publication channels.

\section{ROYAL SCOTTISH FORESTRY SOCIETY CENTENARY VOLUME}

$T$ HE Royal Scottish Forestry Society is the oldest forestry society in Great Britain (the English Society having been founded in 1881), and this year it is celebrating its centenary. In honour of the occasion, the Society proposes to issue four special numbers of its journal, Scottish Forestry, as a cen. tenary volume, each number containing three articles which will deal with all the aspects of forestry, and the first of these numbers has recently been published (Scot. For., 8, No. 1 ; January 1954). It opens with centenary greetings from the president of the Society and of the English Society, the chairman of the Forestry Commission, Lord Radnor, the chairman of the Empire Forestry Association, and the president of the Society of Foresters of Great Britain, and then goes on to the three articles: the history and activities of the Society, 1854-1953, by the honorary secretary of the Society, Sir Samuel Strang Steel; forest policy and legislation affecting Scotland, 1854-1953, by Sir Henry Beresford Pierce, 
of the Forestry Commission; and private forestry in Scotland, by Sir John Milne Home.

The first article recalls how the original president of the Society was James. Brown, at that time deputy surveyor of the Forest of Dean and provisional head forester of Armiston, who is chiefly known as the author of "The Forester", the stendard book on forestry at that period. The Society was formed by a strong committee of nineteen which framed its constitution and its by-laws, subscriptions and so forth. Members were soon forthcoming, and the first Transactions of the Scottish Arboricultural Society, as it was then called, appeared four years later. During the past century the Society was constantly pressing the claims of forestry in Scotland on the Government, and committees and commissions were appointed by the House of Commons, without, however, much practical result until the present century.

In Sir Henry Beresford Pierce's well-informed article he points out that it was the Society (and, in particular, Munro Fergusson, afterwards Lord Novar, Sir John Sterling Maxwell and Lord Lovat) which pressed the Government to form a model State forest to be a pilot scheme to a much larger proposal that the Society put forward, namely, the afforestation of between three and four million acres in Scotland. As a practical outcome of this suggestion, the Royal Commission on Coast Erosion in 1909 proposed alternative schemes for the afforestation of nine million or six million acres in the United Kingdom. It was the First World War which eventually brought these ultimative schemes to a head in the Acland Report and the Government Bill forming the Forestry Commission at the close of the War.

The Society may be congratulated on the proposed centenary volume, for in that should be assembled the true forestry history of the period and the ideas which make for an appreciation of what forests and forestry really imply to a country and its people.

E. P. Stebbing

\section{ADAPTIVE CHANGES IN SUNFLOWER}

G E. BLACKMAN AND G. L. WILSON have . continued their physiological and ecological analyses of plant environment by investigating the adaptive changes in the vegetative growth and development of Helianthus annuus as induced by alterations in light-level (Ann. Bot., 18, No. 69, 71 ; 1954). To this end pot experiments were carried out in which sunflowers in the early vegetative phase were first grown for a period under three levels of light $(1 \cdot 0,0 \cdot 5$ and $0 \cdot 24$ daylight). Afterwards, pots from each light-group were subdivided into three so that in a second period plants could be subjected to the nine possible combinations of the same three light-intensities before and after transference. During the post-transference period of adaptation to either a higher or a lower intensity the net assimilation-rate was found to be logarithmically proportional to the light received and there was no residual effect of the initial light treatments. Eight days after transference the leaf-area ratios (total leaf area/total plant weight) at each light-level became adjusted to a new equilibrium irrespective of the large initial differences in the ratio induced by the pre-transference intensities. In both periods there was an inverse and logarithmic relationship between the leaf-area ratio and falling light-intensity; consequently, the greater the degree of shading in the pre-transference period, the higher were the mean ratios in the second period. Since the relative growth-rate is the product of the net assimilation-rate and the leaf-area ratio, the variations in the leaf-area ratio in the post-transference period induced by the initial light treatments were reflected in the relative growth-rates. Thus plants. transferred from a lower to a higher light-intensity were leafier and initially grew faster than plants maintained at the higher level in both periods: the converse conditions led to a reduction in the growthrate.

It was observed that shading depresses the growth of the roots, but that the relative growth-rate is dependent on the light-intensity in both the pretransference and post-transference periods. The growth-rate was maximal when plants were moved from the lowest to the highest intensity.

In terms of leaf weight, decreasing the lightintensity decreased the relative growth-rate and there was no consistent after-effect of the initial light treatments. The rate of expansion in leaf area tends to be highest at the intermediate level of 0.5 daylight, and over all the post-transference intensities the rates were maximal for those plants which received initially full daylight. The ratio of leaf area to leaf weight was inversely and logarithmically proportional to the light-level. After transference, the slopes of the regressions were independent of the initial light treatments; but the mean ratios were inversely correlated with the initial degree of shading. These observations are discussed with particular reference to the control of growth exerted by growthregulating substances: on the basis of existing knowledge, no adequate interpretation of the adaptive changes yet seems possible.

\section{DISTRIBUTION OF LAMINARIACEAE AROUND SCOTLAND}

\author{
By F. T. WALKER
}

Institute of Seaweed Research, Musselburgh, Midlothian

TIFTY-NINE detailed surveys, covering 80,000 acres of the sub-littoral zone off the north-east, south-east and south-west mainland of Scotland, the Isle of Skye and several of the islands of Orkney, have been completed by the Botanical Division of the Institute of Seaweed Research.

The detailed surveys were preceded by aerial photogrammetric surveys. They were carried out at all times of the year and during seven years, 1946-53, and so include seasonal and cyclic changes. They covered areas of the sea-bed from low-water mark down to ten fathoms $(19 \mathrm{~m}$.), where the dominant species was either Laminaria cloustoni, L. digitata or $L$. saccharina. (Some surveys were restricted to depths of 1-6 fathoms.) Tidal streams ranged from 0 to $7 \mathrm{knots}$ and tides from low-water mark to 3 fathoms $(6 \mathrm{~m}$.) according to time and location.

In the course of the fifty-nine surveys, operated from motor-vessels, some 50,000 quadrats were taken from the sea-bed by means of calibrated spring-grabs which close by trigger action on reaching the bottom ${ }^{1}$.

The 1946-49 surveys employed methods of quadrat sampling along transects measured'by range-finder, 